\title{
Patients knowledge about side effects of orthodontic treatment
}

\author{
Mia Amalia*), Haru Setyo Anggani*, Nia Ayu Ismaniati* \\ *Department of Orthodontics Faculty of Dentistry Universitas Indonesia, Jakarta
}

\section{ABSTRACT}

Disharmonious of dental arrangement can possibly create problems for the patient, such as the masticatory function, esthetical, psychosocial, and also the increased risk of trauma and periodontal disease. These are reasons for patient to seek orthodontic treatment. The aim of this study was to know the patient's knowledge about the side effects possibility that they receive during orthodontic treatment. The side effects include pain experience during orthodontic treatment, the possibility of soft tissue damage, email demineralization, loss of tooth vitality, periodontal problem, root resorption, temporomandibula joint disorders and relapse. A cross sectional study was conducted in patients who registered at Orthodontic Department, Faculty of Dentistry, Universitas Indonesia on March-June 2009. The participants of this study were 100 patients, consist of 86 women and 14 men respectively. Twenty seven questions about the side-effects of orthodontic treatment were used to obtain the patient's knowledge and the result was categorized into 3 groups, good, average and poor. The result of the study showed that patient's knowledge about the side effect of pain experience during orthodontic treatment was average and the patient's knowledge about the possibility of soft tissue damage due to orthodontic treatment was good. However, the patient's knowledge about the possibility of email demineralization, loss of tooth vitality, periodontal problem, root resorption, temporomandibula joint disorders and relapse due to orthodontic treatment was low.

Key words: Patient's knowledge, side effects of orthodontic treatment

\section{ABSTRAK}

Susunan gigi yang tidak harmonis menyebabkan masalah pada pasien, seperti gangguan fungsi pengunyahan, estetik, psikososial dan juga bertambahnya trauma dan penyakit periodontal. Tujuan penelitian ini adalah untuk mengetahui pengetahuan pasien tentang kemungkinan efek samping yang mereka terima selama perawatan ortodonti. Efek samping termasuk pengalaman rasa sakit selama perawatan ortodonti, kemungkinan kerusakan jaringan lunak, demineralisasi email, kehilangan vitalitas gigi, masalah periodontal, resorpsi akar, gangguan sendi temporomandibula dan kekambuhan. Sebuah studi cross sectional dilakukan pada pasien yang terdaftar di Departemen Ortodonti Fakultas Kedokteran Gigi Universitas Indonesia pada bulan Maret sampai Juni 2009. Subjek penelitian sebanyak 100 pasien, terdiri atas 86 perempuan dan 14 laki-laki. Masing-masing diberikan 27 pertanyaan tentang efek samping perawatan ortodonti, yang digunakan untuk mendapatkan pengetahuan pasien dan hasilnya

\footnotetext{
*)Correspondence author: Mia Amalia, Department of Orthodontic Faculty of Dentistry Universitas Indonesia
} Jl. Salemba Raya No. 4 Jakarta Pusat-Indonesia, Tel./Fax: +62-21-31930270/31931412 
dikategorikan menjadi 3 kelompok, baik, rata-rata dan buruk. Hasil penelitian menunjukkan bahwa pengetahuan pasien tentang efek samping mengalami rasa sakit selama perawatan ortodontik adalah rata-rata dan pengetahuan pasien tentang kemungkinan kerusakan jaringan lunak akibat perawatan ortodontik adalah baik. Namun, pengetahuan pasien tentang kemungkinan demineralisasi email, kehilangan vitalitas gigi, masalah periodontal, resorpsi akar, gangguan sendi temporomandibula dan kekambuhan karena perawatan ortodontik rendah.

Kata kunci: Pengetahuan pasien, efek samping perawatan ortodontik

\section{INTRODUCTION}

Disharmonious dental arrangement can possibly create problems for the patient, such as the masticatory function, esthetical, psychosocial, and also the increased risk of trauma and periodontal disease. These are reasons for patient to seek for orthodontic treatment. ${ }^{1,2}$ Several studies have been done to find out the need of orthodontic treatment in Indonesia that depicted phenomenon of social need of orthodontic treatment. ${ }^{3-5}$ This phenomenon describes the people knowledge that orthodontic treatment can improve their teeth relation. But, how about the patient knowledge regarding its adverse effects that can possibly occur as a result of orthodontic treatment? This encouraged us to study the knowledge of patients which will be treated orthodontically regarding the adverse effects at the Orthodontic Department of Educational Oral and Dental Hospital, Department of Educational Oral and Dental Hospital Faculty of Dentistry Universitas Indonesia (RSGMP FKG UI).

The objective of this study was to obtain the general perspective of patients knowledge regarding the adverse effect of orthodontic treatment, by which we can provide information for clinician regarding the patient knowledge of orthodontic adverse effect which come to RSGMP-FKG UI and also provide information for the patients regarding the adverse effects which can possibly happen as orthodontic treatment commenced.

\section{METHODS}

This was an observational descriptive study with cross sectional design and commenced at the Orthodontic Clinic RSGMP-FKG UI from March to June 2009. Subjects of this study were the new patient ${ }^{5}$ which came to the clinic with criteria of subjects such as patient had to be registered in RSGMP-FKG UI and had not ever been treated until March 2009, had not ever been explained regarding the orthodontic treatment adverse effect and agreed to follow the study.

Based on the formula of single sample amount for nominal data was obtained the sample amount of 97 respondents which subsequently was rounded up to 100 respondents. ${ }^{6}$ Sampling technique was non-random with purposive sampling. Questionnaire test, was conducted for 2 weeks ( 20 February-6 March 2009) with 11 new patient as respondents. Based on the SPSS program version 17 calculation, the questions in the questionnaire could be stated as reliable and valid. Permission from the ethical commision was obtained, followed by data collection by questionnaire. Data in form of 'yes' or 'no' answers were grouped based on its variable. Data valuation, was given by score 1 (one) for every correct answer and 0 (null) for every incorrect answer. The respondent knowledge level categorized as good, average, or poor for every variable. The respondent categorized as good knowledge if they had total score 3, aver-

Table 1. Respondent characteristics

\begin{tabular}{|c|c|c|}
\hline \multicolumn{2}{|c|}{ Respondent characteristics } & \multirow{2}{*}{$\begin{array}{c}\% \\
14\end{array}$} \\
\hline Gender/sex & Men & \\
\hline & Women & 86 \\
\hline \multirow[t]{4}{*}{ Age } & $<13$ years & 2 \\
\hline & $13-18$ years & 23 \\
\hline & $19-40$ years & 73 \\
\hline & $>40$ years & 2 \\
\hline \multirow[t]{7}{*}{ Educational level } & Elementary & 1 \\
\hline & Yunior high school & 8 \\
\hline & High school & 18 \\
\hline & College student & 44 \\
\hline & Diploma & 13 \\
\hline & Graduate & 14 \\
\hline & Post Graduate & 2 \\
\hline
\end{tabular}


age/medium as they obtained score 2 . Respondent with total score less than 2 could be categorized into less informed; Univariate analysis to obtain the proportion level of respondent knowledge for each variable was done.

\section{RESULTS}

This study was performed in March-June 2009 and obtained 100 respondents of new patients who were treated orthodontically in Orthodontic Department of RSGMP FKG UI. The respondent characteristics grouped to gender, age and educational level and shown on the Table 1. While the information source for patients regarding the orthdontic treatment shown in Table 2.

The respondent knowledge was obtained by completing the questionnaire that contained

Table 2. Information resources of orthodontic treatment

\begin{tabular}{clcc}
\hline No & \multicolumn{1}{c}{ Information resources } & N & $\%$ \\
\hline 1. & Friends & 35 & 35 \\
2. & Electronic media & 2 & 2 \\
3. & Print media & 0 & 0 \\
4. & Friends and electronic media & 26 & 26 \\
5. & Friends and print media & 7 & 7 \\
6. & Print media and electronic media & 2 & 2 \\
7. & Friends, print media, and electronic & 28 & 28 \\
\hline & Total & 100 & 100 \\
\hline
\end{tabular}

Table 3. The respondents answers distribution of every answer in particular variables summarized

\begin{tabular}{|c|c|c|c|c|}
\hline \multirow{2}{*}{ Variables } & \multirow{2}{*}{ Questions } & \multicolumn{2}{|c|}{ Answer } & \multirow{2}{*}{$\Sigma$} \\
\hline & & Yes & No & \\
\hline \multirow[t]{3}{*}{ Pain } & Orthodontic treatment can be painful. & 79 & 21 & 100 \\
\hline & The pain will eventually relieve. & 85 & 15 & 100 \\
\hline & The pain can be relieved by painkillers/analgesics. & 41 & 59 & 100 \\
\hline \multirow[t]{3}{*}{ Soft tissue trauma } & The brackets or wires can cause wounds or ulcers on the cheek or lips. & 72 & 28 & 100 \\
\hline & The ulcers can be infected if oral hygiene is poorly maintained. & 91 & 9 & 100 \\
\hline & The ulcers caused by orthodontic appliances can be cured. & 73 & 27 & 100 \\
\hline Defect of dental & Orthodontic appliances can cause defects on the enamel surfaces. & 21 & 79 & 100 \\
\hline \multirow[t]{2}{*}{ enamel } & Orthodontic appliances can cause white spot on the enamel of the teeth. & 10 & 90 & 100 \\
\hline & Toothpaste with fluoride can prevent enamel defects. & 53 & 47 & 100 \\
\hline \multirow[t]{3}{*}{ Vitality } & Orthodontic appliances do affect the dental nerves/pulp. & 33 & 67 & 100 \\
\hline & Orthodontic appliances can cause the dental nerves to be devitalized. & 7 & 93 & 100 \\
\hline & $\begin{array}{l}\text { Orthodontic appliances can still be applied on a tooth that had been treated } \\
\text { endodontically. }\end{array}$ & 28 & 72 & 100 \\
\hline \multirow[t]{3}{*}{ Periodonal tissues } & $\begin{array}{l}\text { Orthodontic appliances will somehow make it difficult for patient to maintain } \\
\text { their oral health. }\end{array}$ & 44 & 56 & 100 \\
\hline & $\begin{array}{l}\text { Orthodontic appliances can cause dental plaque easily attach on the teeth } \\
\text { surfaces. }\end{array}$ & 59 & 41 & 100 \\
\hline & $\begin{array}{l}\text { Gingivitis and gum swelling occur while wearing the orthodontic appliances as a } \\
\text { result from poor oral health. }\end{array}$ & 67 & 33 & 100 \\
\hline \multirow[t]{3}{*}{ Root resorption } & Orthodontic appliances can cause injury of the roots. & 15 & 85 & 100 \\
\hline & The period length of wearing orthodontic appliances affects the root injury. & 18 & 82 & 100 \\
\hline & Root resorption as a result of orthodontic treatment can be fixed. & 86 & 14 & 100 \\
\hline \multirow[t]{3}{*}{ TMJ problems } & Have you ever heard about joint clicking sound. & 32 & 68 & 100 \\
\hline & Joint problem can be caused by malocclusion. & 47 & 53 & 100 \\
\hline & Maltreatment of orthodontic can cause problems on the temporomandibular joint. & 63 & 37 & 100 \\
\hline \multirow[t]{3}{*}{ Relapse } & Teeth positions after orthodontic treatment will be stable. & 68 & 32 & 100 \\
\hline & $\begin{array}{l}\text { After being moved with orthodontic appliances teeth have tendency to return to } \\
\text { its former position. }\end{array}$ & 52 & 48 & 100 \\
\hline & $\begin{array}{l}\text { After fixed orthodontic appliances have been removed it will need retainers in } \\
\text { order to stabilize the new teeth positions. }\end{array}$ & 54 & 46 & 100 \\
\hline
\end{tabular}


Table 4. Proportion of respondent knowledge regarding the adverse effect of orthodontic treatment of variable

\begin{tabular}{lccc}
\hline \multirow{2}{*}{ Variable } & \multicolumn{3}{c}{$\begin{array}{c}\text { Categories of respondent } \\
\text { knowledge (\%) }\end{array}$} \\
\cline { 2 - 4 } & Good & Moderate & Poor \\
\hline Pain & 33 & 48 & 19 \\
Soft tissue trauma & 53 & 35 & 12 \\
Dental enamel defect & 7 & 14 & 79 \\
Tooth vitality & 4 & 14 & 82 \\
Periodontal tissues & 28 & 28 & 44 \\
Root resorption & 5 & 6 & 89 \\
TMJ problem & 22 & 20 & 58 \\
Relapse & 12 & 29 & 59 \\
\hline
\end{tabular}

questions regarding the adverse effects of orthodontic treatment. Those adverse effects were pain, soft tissue trauma, defect of the dental enamel, tooth vitality, periodontal issues, root resorption, temporomandibular joint disorder and relapse. ${ }^{6-8}$

Conclusion of patient knowledge regarding each variable will be valued by summarizing the total score of each respondent. Correct answer will be scored 1 and the wrong answer will be zero (0). The knowledge of each respondent will be rated as good if the total score was 3 for each variable, and it will be moderate/medium if the total score was 2 for each variable. While if the total score were less than 2 , it was categorized as poor.

\section{DISCUSSION}

This study was done on the prospective orthodontic patients that had never been explained regarding the adverse effect of orthodontic treatment and agreed to follow the entire process of this study. Every new patient was informed regarding this study objectives, and were asked to sign an informed consent.

As much as $86 \%$ of the patients were women. This corresponded with a study by Burraqaison ${ }^{5}$, which suggested that most patients who seek for orthodontic treatment were women. Are this can be understood because of women were more concerned regarding their esthetics than men. The second characteristic of this study was age. Even though no age limit in this study, it was predominated by patients aged 19-40 years old.
This seemed natural, because of at those ages women are really concerned about their looks.

Most of the respondents gained information from friends (35\%). This shows that, friends played an important role of information distribution regarding orthodontic treatment, particularly pleasant and unpleasant experiences about it.

Among the adverse effects of orthodontic treatment, only $19 \%$ of respondent had poor knowledge about pain. This might be because friends as their main information resource had experienced pain and told them so, therefore the respondent knowledge about pain in orthodontic treatment was good. Another adverse effect of orthodontic treatment was the trauma of soft tissues. Out of the 3 questions asked, majority of the respondent could be categorized as having good knowledge (35\%). That was understandable, because wound or ulcers most frequently occurs during orthodontic treatment.

Respondent knowledge regarding adverse effect on enamel based on the answers to all 3 questions asked, $79 \%$ of the respondent had poor knowledge as a cause of orthodontic treatment. Lack of knowledge about this adverse effect, is likely because of friends as their main source of information have not experienced it. Another possibility, that the orthodontic appliances caused the patients to maintain their oral health cautiously, to avoid the possible enamel defects. Nevertheless most of the respondent were aware that fluorised toothpaste could prevent enamel defects.

Similarly with the adverse effect of enamel defect, the effect for pulp vitality was less known by the respondents. From their answers to the 3 questions asked, $82 \%$ of the respondent categorized as poor knowledge about it. This was simply because of their friends as their main source of information did not experience devitalized pulp after orthodontic treatment. Another adverse effect was the periodontal tissue problem. The respondent answers showed that the respondens knew that either plaque or gingivitis could easily occur if they fail to maintain their oral health. Nevertheless, respondent did not presume that dental wires added difficulties in maintaining their oral health. The respondent knowledge regarding the periodontal issues, generally could be categorized as good. But unfortunately their 
knowledge regarding the periodontal issues if it were to be related with orthodontic treatment seemed unfavorable.

The other adverse effect of orthodontic treatment was the possibility of root resorption. Based on the respondent answers out of 3 questions asked, we concluded that $89 \%$ respondent possessed a poor knowledge regarding it. This of course was predictable, because roots could not be seen in the oral cavity, unless a dental radiograph was made.

The possibility of temporomandibular joint disorder was one of the orthodontic treatment adverse effect. Majority of the respondents did not or never heard of clicking sound of the jaw joint. They also did not know that jaw joint problems could be caused by malrelation of their teeth. Nonetheless, most of the respondent presumed that improper orthodontic treatment could cause jaw joint problems. Which is surprising.

Based on the respondent answers out of the 3 questions asked, we concluded that $58 \%$ of the respondentknowledgeregarding theadverseeffects of orthodontic treatment on temporomandibular joint problems were poor. During the study, we frequently had to explain about the clicking sound of the jaw joint. Because respondents did not quite understand the question.

Another adverse effect was the relapse possibility after orthodontic treatment. Most of the respondent stated that the obtained teeth positions after orthodontic treatment were stable, but many of the respondent also answered that moved teeth could possibly return to its original position. This contradictive answers showed that respondent possessed lack of knowledge regarding stability. Out of 100 respondents which answered those three questions, $59 \%$ of them possessed poor knowledge regarding it. The poor level of knowledge about this adverse effect was possibly because their friends as source of information had not experienced it after finished orthodontic treatment.

Lack of respondents knowledge about the adverse effects of orthodontic treatment, especially the invisible adverse effects in oral cavity can be understood as they have minimum access of information. Based on this study, it showed that most of information obtained by respondent came from their friends or relatives whom had being treated or had finished orthodontic treatment, thus it is understandable that the respondent knowledge came mainly from what had their informants experienced. The adverse effects regarding organs such as root tanporonan tanporonan joint are not general knowledge easily dibular accessed by any respondent.

Besides, the low level of knowledge of the patient could possibly caused by questions in the questionnaire which were not clear enough, even though we had applied validity and reliability tests. Indeed during the study, we frequently had to explain about the root resorption, jaw joint clicking sound, and stabilization after treatment, even though most of the respondent had fairly good level of education. Therefore a better questionnaire which can be used to study larger range of ages and more variety of educational level is needed.

\section{CONCLUSION}

The knowledge level of orthodontic prospective patients in Orthodontic Clinic of RSGMP-FKG UI in the period of March-June 2009 regarding the adverse effects of orthodontic treatment is as follows: The knowledge level about pain adverse effect as a result of orthodontic treatment was moderate/medium. The knowledge about soft tissue trauma as a result of orthodontic treatment was good. Their knowledge regarding the enamel defect, pulp vitality, periodontal issues, root resorption, temporomandibular joint disorder and the possibility of relapse that resulted from orthodontic treatment were poor.

\section{REFERENCES}

1. Jacobson A. Psychological aspect of dentofacial esthetics and orthognatic surgery. Angle Orthodontist 1984;54:18-35.

2. Proffitt WR, Fields HW. Contemporary orthodontics. $3^{\text {rd }}$ ed. Philadelphia: C.V. Mosby: Co; 2000.

3. Agusni T. Peran ortodontis dalam menunjang kedokteran gigi komunitas. Majalah Kedokteran Gigi UNAIR 1999:102-5.

4. Lamtiur E, Husein F, Krisnawati. Kebutuhan perawatan ortodonti remaja usia 12-13 tahun di Jakarta Selatan (Studi epidemiologi diukur dengan IOTN). J Dentistry 2005;17:2:41-9. 
5. Burraqaison. Kebutuhan dan permintaan perawatan ortodonti pada remaja Jakarta (Survai melalui wawancara telepon). J Dentistry 2005;17:2

6. Moenssen $M B$, Zablocki H. Informed consent for treatment. [cited 2008 Des 10]. Available from: http://www.dexterortho.com.
7. Lau PYW, Wong RWK. Risks and complications in orthodontic treatment. Hong Kong Dent J 2006;3:15-22.

8. Travess H, Robert-Harry D, Sandy J. Orthodontics. Part 6. Risks in orthodontic treatment. British Dent J 2004;196;2:71-7. 